\title{
Monitoring Of Helicoverpa Armigera (Hubner) (Lepidoptera: Noctuidae) Through Pheromone Traps In Chickpea (Cicer Arietinum) Crop And Influence Of Some Abiotic Factors On Insect Population.
}

\author{
Pawan Kumar Sharma ${ }^{1}$, Uttam Kumar ${ }^{2}$, Sapana Vyas ${ }^{3}$, Subrat Sharma ${ }^{4}$ and \\ Surabhi Shrivastava ${ }^{5}$. \\ ${ }^{1,2,3}$ Research scholars (Zoology), Govt. P.G. College Kota ; 4,5-Lecturers in Zoology, Govt. P.G. College Kota
}

\begin{abstract}
Monitoring of Helicoverpa armigera (Hubner) male moths through pheromone traps was carried out in chickpea crop field at village Kapren, dist. Bundi during 2011-12. Maximum number of male moths trapped were 105.66/trap/week, while maximum number of larvae was 30.0/10 plants recorded during $12^{\text {th }}$ standard week (19 March -25 March). Abiotic factors like maximum temperature and minimum temperature had positive correlation with male moth catches and larval population of Helicoverpa armigera while, relative humidity had negative correlation with male moth catches and larval population of Helicoverpa armigera.
\end{abstract}

Key words: Pheromone trap, Helicoverpa armigera, Integrated Pest Management, Abiotic factors.

\section{Introduction:}

Chickpea is an important pulse crop of India, known as king of pulses. Insect pests are major threat to agricultural production. Helicoverpa armigera is a polyphagous insect pest of many agricultural and horticultural crops across the world (Fitt, 1989), because of its high fecundity, migratory behavior, high adaptation to various climatic conditions and development of resistance towards wide range of insecticides. However it is a polyphagous insect pest but chickpea is its most preferred host (Tripathi and Sharma, 1985). Recent climatic changes have also influenced the population of Helicoverpa armigera in different crops (Srivastava, 2009). Pheromone traps are the important component in integrated pest management programme, for monitoring its population. Present investigation was carried out to monitor population of Helicoverpa armigera and its relationship with abiotic factors such as minimum, maximum temperatures and relative humidity.

\section{Material and Methods:}

For monitoring of Helicoverpa armigera through pheromone traps, investigation was conducted at village Kapren of district Bundi, Rajasthan in chickpea crop field during 2011-12. For this purpose three pheromone traps were installed in the field with the help of bamboo sticks at $2.0 \mathrm{~m}$ height above the ground level. The male moth of Helicoverpa armigera were attracted towards pheromone trap and slipped into plastic polythene bag through the funnel. Observations on male moth catches were recorded daily from $17^{\text {th }}$ December to $8^{\text {th }}$ April 2012. Pheromone lure was replaced by a new one at every 14 days interval. Observations on larval population were recorded at weekly interval from ten randomly selected plants. The relationship between abiotic factors, male moth catches and larval population was calculated by using simple correlation co-efficient formula.

\section{Result and Discussion:}

Table: 1 shows that first trap catch of male moth of Helicoverpa armigera as recorded during $6^{\text {th }}$ standard week (Feb. $05^{\text {th }}$-Feb. $11^{\text {th }}$ ) was 12.33 moths/trap/week which increased gradually and reached its peak ( 105.66 moths/trap/week ) during $12^{\text {th }}$ standard week (March $19^{\text {th }}$-March $25^{\text {th }}$ ) and soon after decreased to 31.66 moths/trap/week in $14^{\text {th }}$ standard week (April $2^{\text {nd }}-$ April $8^{\text {th }}$ ). Almost similar kind of observations were observed by Shah and Shahzad. (2005), who reported its low population during $49^{\text {th }}$ to $6^{\text {th }}$ standard weeks but increased from $7^{\text {th }}$ standard week onwards and declined again during $14^{\text {th }}$ standard week. Mahapatra et al. (2007) observed higher number of moths trapped during March and April months. Present findings were in favour of Anonymous (1988) who reported that incidence of Helicoverpa armigera commenced during mid January, increased gradually in the month of February and reached on peak at the end of March, then decreased rapidly within two weeks onward. 
In the present work, adult male moth catches remained zero from $51^{\text {st }}$ to $05^{\text {th }}$ standard week, however incidence of larval population was commenced much earlier (2.33 larvae/10 plants) from $2^{\text {nd }}$ standard week (Jan. 08 ${ }^{\text {th }}-$ Jan. $\left.14^{\text {th }}\right)$ and reached its peak (30.0 larvae/plants) on $12^{\text {th }}$ standard week. Anwar et al. (1994) also reported high larval population during February and March.

Table 2 shows correlation between abiotic factors (minimum ,maximum temperatures and relative humidity) and male moth trap catches and larval population of Helicoverpa armigera . Present findings revealed that adult male moth catches in pheromone traps positively correlated ( $\mathrm{r}=0.77$ and $\mathrm{r}=0.63)$ with maximum and minimum temperatures, while it was negatively correlated $(r=-0.79)$ with relative humidity. Similar kind of observations were also recorded by Rothschild et al.(1981), Yadav and Lal (1988), Deshpande and Khan (1990), Yadav et al.(1991), Venkataiah and Subbaratnam (1992), Lal (1996), Gour (1997), Ganguli et al. (1998), Metange et al.(2004). However Upadhyay et al.(1989) reported positive correlation with maximum temperature $(\mathrm{r}=0.63)$ and minimum temperature $(\mathrm{r}=0.67)$ as well as relative humidity $(\mathrm{r}=0.59)$.

Correlation between larval population and abiotic factors (minimum, maximum temperatures and relative humidity) was recorded as $\mathrm{r}=0.69, \mathrm{r}=0.77$ and $\mathrm{r}=-0.89$ respectively.

Minimum and maximum temperatures were positively correlated with larval population build up, while it was negatively correlated with relative humidity. These findings are in favour of Sharma et al. (2005) who reported minimum and maximum temperatures $(\mathrm{r}=0.828$ and $\mathrm{r}=0.808)$ were positively correlated, while morning and afternoon relative humidity ( $\mathrm{r}=-0.725$ and $\mathrm{r}=-0.595)$ were negatively correlated. In present investigation correlation between male moth catches and larval population was $r=0.8329$ recorded.

Table 1 Pheromone trap catches and larval poulation of Helicoverpa armigera at Kapren (Bundi) during 2011-2012.

\begin{tabular}{|c|c|c|c|c|c|c|}
\hline \multirow{2}{*}{ 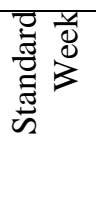 } & \multirow[t]{2}{*}{ Period } & \multicolumn{2}{|c|}{$\begin{array}{l}\text { Mean temperature } \\
\left({ }^{\circ} \mathrm{C}\right)\end{array}$} & \multirow[t]{2}{*}{$\begin{array}{l}\% \text { Relative } \\
\text { Humidity }\end{array}$} & \multirow{2}{*}{$\begin{array}{l}\text { Average no. of } \\
\text { male Moths } \\
\text { /trap/week }\end{array}$} & \multirow{2}{*}{$\begin{array}{l}\text { Average no. } \\
\text { of larvae/ } 10 \\
\text { plants }\end{array}$} \\
\hline & & $\begin{array}{l}\text { Minim } \\
\text { um }\end{array}$ & $\begin{array}{l}\text { Maximu } \\
\mathrm{m}\end{array}$ & & & \\
\hline 51 & Dec. 17- Dec.23 & 7.61 & 24.15 & 71.00 & 0 & 0.00 \\
\hline 52 & Dec. 24- Dec. 31 & 7.62 & 21.84 & 77.12 & 0 & 0.00 \\
\hline 01 & Jan. 01- Jan. 07 & 9.92 & 20.50 & 91.28 & 0 & 0.00 \\
\hline 02 & Jan. 08- Jan. 14 & 5.75 & 19.78 & 79.71 & 0 & 2.33 \\
\hline 03 & Jan. 15- Jan. 21 & 6.74 & 21.16 & 71.43 & 0 & 5.00 \\
\hline 04 & Jan. 22- Jan. 28 & 6.89 & 20.61 & 73.71 & 0 & 9.00 \\
\hline 05 & Jan. 29- Feb. 04 & 6.65 & 20.67 & 71.71 & 0 & 13.33 \\
\hline 06 & Feb. 05- Feb. 11 & 7.78 & 21.02 & 60.86 & 12.33 & 16.33 \\
\hline 07 & Feb. 12- Feb. 18 & 9.35 & 23.19 & 63.71 & 15.66 & 18.33 \\
\hline 08 & Feb. 19- Feb. 25 & 11.79 & 28.47 & 56.57 & 23.66 & 17.66 \\
\hline 09 & Feb. 26- Mar. 04 & 10.74 & 26.73 & 51.50 & 15.00 & 17.66 \\
\hline 10 & Mar. 05-Mar. 11 & 12.53 & 29.04 & 38.29 & 54.66 & 19.00 \\
\hline 11 & Mar. 12-Mar. 18 & 12.63 & 29.56 & 49.57 & 73.00 & 25.33 \\
\hline 12 & Mar. 19-Mar. 25 & 14.06 & 32.74 & 42.29 & 105.66 & 30.00 \\
\hline 13 & Mar. 26-Apr. 01 & 17.36 & 36.99 & 37.71 & 79.66 & 26.00 \\
\hline 14 & Apr. 2-Apr. 08 & 23.12 & 38.13 & 38.00 & 31.66 & 23.66 \\
\hline
\end{tabular}

Table 2: Correlation co-efficient between weather parameters, male moth catches and larval population of Helicoverpa armigera at Kapren (Bundi) during 2011-2012.

\begin{tabular}{|l|l|l|l|}
\hline & Minimum temperature & Maximum temperature & Relative humidity \\
\hline Moths & 0.6382 & 0.7778 & -0.7952 \\
\hline Larvae & 0.6995 & 0.7759 & -0.8908 \\
\hline
\end{tabular}




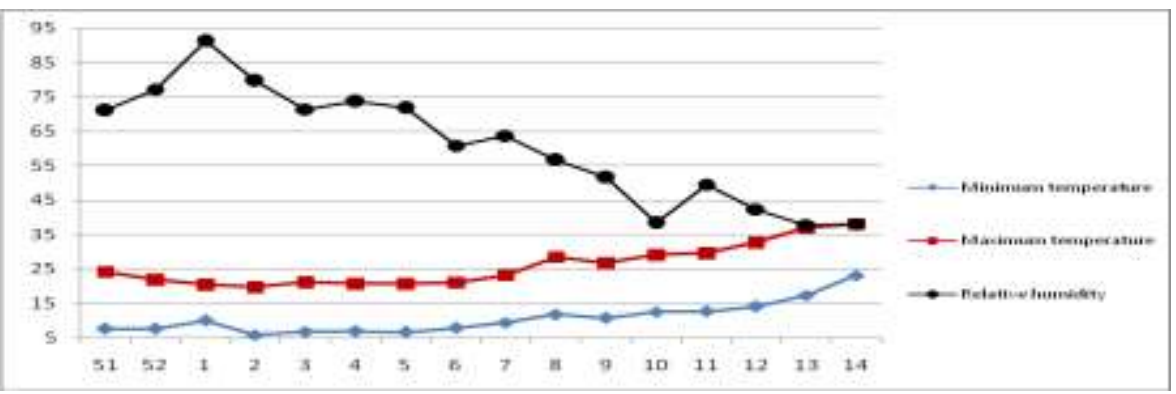

Figure 1: Fluctuations in weather parameters at Kapren (Bundi) during 2011-2012.

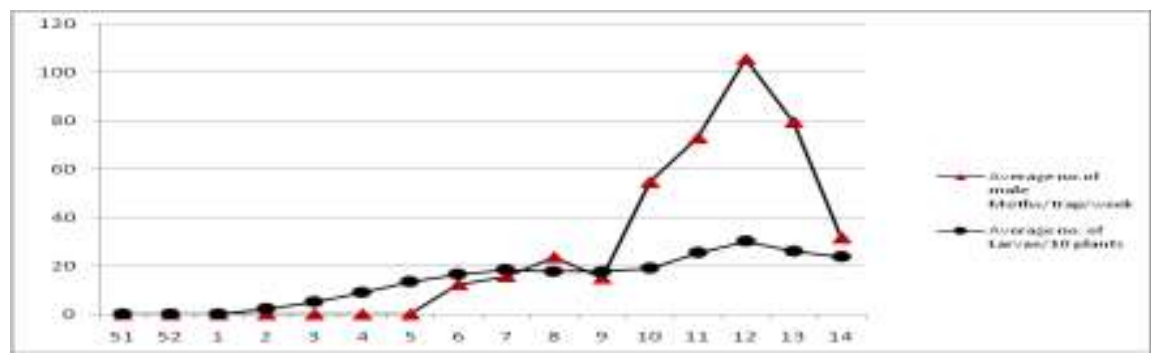

Figure 2: Pheromone trap catches of male moths and larval population of Helicoverpa armigera at Kapren

(Bundi) during 2011-2012.

\section{Coclusion:}

Squeeze of present study is that pheromone traps are important tool for monitoring of Helicoverpa armigera population. In the present study peak trap catches of male moth are indications of high larval population in the field and control measures through integrated pest management techniques without indiscriminate use of insecticide may be implemented immediately.

\section{References:}

[1] Anonymous 1988. Final progress report (1984-1987), ICAR scheme on determination of economic threshold levels and off season bio-ecology of important insect pests of pulses. Department of Entomology, RCA, Udaipur (India):30-32.

[2] Anwar, M.; Shafique, M.; Ahmad, M. and Shaloori, A.P. 1994. Incidence of attack and population fluctuation of Heliothis armigera in relation to chickpea phenology and environmental factors. Proceedings of Pakistan Congress of Zoology,(12).

[3] Deshpande, R.R. and Khan, L. 1990. Moth catches in pheromone traps in relation to meteorological conditios. Jour. Cotton Res. Devlop. 4(1): 93-99.

[4] Fitt, G.P. 1989. The ecology of Heliothis species in relation to agroecosystem. Annual. Rev. Ento., 34:17-52.

[5] Ganguli, R.N.; Dubey, V.K. and Yadu, Y.K. 1998. Studies on population dynamics of Helicoverpa armigera based on light trap catches in Chhattisgarh region of Madhya Pradesh. Abstract in Entomology in $21^{\text {st }}$ century, April $30^{\text {th }}-2^{\text {nd }}$ May: 257.

[6] Gour, I.S. 1997. Management of major pests of tomato, Lycopersicum esculentum Mill. during summer. M.sc.(Ag.) Thesis, S.K.N. college of Agriculture, RAU, Bikaner.

[7] Lal, O.P. 1996. An out break of pod borer, Helicoverpa armigera on chickpea in eastern Uttar Pradesh. Jour. Entomol. Res. 20: $179-181$.

[8] Metange, K.K. ; Khandge, S.V.; Upadhyay, A.P. and Agrawal,K.K. 2004. Influence of temperature on incidence of gram pod borer Helicoverpa armigera Hubner. Ind. Jour. Ent., 66(3): 272-274.

[9] Mahapatra, S.D.; Aswal, J.S. and Mishra, P.N. 2007. Monitoring population dynamics of tomato fruit borer, Helicoverpa armigera Hubner moths through pheromone traps in Uttaranchal Hills. Ind. Jour. Ent. 69(2): 172-173.

[10] Rothschild, G.H.L.; Wilson, A.C.L. and Malafant, K.W. 1981. Preliminary studies on the female sex pheromones of Heliothis sp. and their possible use in control programme in Australia. Proceedings of International workshop on Heliothis management, ICRISAT, centre, Patancheru, India.

[11] Shah, Z.A. and Shahzad, Md. K. 2005. Population fluctuations with reference to different developmental stages of Helicoverpa armigera ( Lepidoptera:Noctuidae) on chickpea and their relationship with the environment. Inter. Jour. Agri. Bio.,7(1):90-93.

[12] Sharma, A.; Jacob, S.P.; Saravanan, L.; Sharma, N. and Gupta, P. 2005. Seasonal incidence of Helicoverpa armigera (Hub.) on chickpea. National Conference on Applied Entomology, Udaipur, September 26-28: 16-17.

[13] Srivastava, C.P. 2009. Impact of climate change on insect pests of pulses and their management. 3-5 in National Conference: Applied Entomology, Impact of Global Warming on the incidence and management of insect pests in agriculture, Entomological Research Association, MPUAT, Udaipur, Rajasthan, India.

[14] Tripathi, S.R. and Sharma, S.K. 1985. Population dynamics of Helicoverpa armigera (Hub.) (Lepidoptera, Noctuidae) on gram in the Terai belt of NEUP. Giarnale Italiana di Entomologia, 2(10):347-352.

[15] Upadhyay, V.R.; Vyas, H.N. and Sherasiya, R.A. 1989. Influence of weather parameters on larval population on Heliothis armigera Hubner on ground nut. Ind. Jour. Pl. Prot., 17(1) 85- 87.

[16] Venkataiah, M., and Subbaratnam, G.V. 1992. Influence of weather factors on the abundance of Helicoverpa armigera (Hubner). Ind. Jour. Eco., 19 (1):55-60.

[17] Yadav, C.P. and Lal, S.S 1988. Relationship between certain abiotic and biotic factors and occurrence of gram pod borer, Heliothis armigera (Hub.) on chickpea. Entomon., 13(3-4):269-273.

[18] Yadava ,C.P.; Lal, S.S.; Ahmad, R. and Sachan, J.N. 1991. Influence of abiotic factors on relative abundance of pod borers of chickpea (Cicer arietinum). Ind. Jour. Agri. Sci., 61(7):512-515. 